症例

腐蝕性食道炎に合併した食道癌の 1 例

横須賀市立市民病院外科

渡会伸治大木繁男杉田昭

鈴木良人

同臨床病理科

小沢 尚男子

\title{
A CASE OF CARCINOMA OF THE ESOPHAGUS DEVELOPED IN CORROSITIVE STRICTURE
}

\author{
Shinji TOGOH, Shigeo OHKI, Akira SUGITA \\ and Ryoto SUZUKI
}

Division of Surgery, Yokosuka City Hospital, Kanagawa

Utsuhiko OZAWA

Division of Clinical Pathology, Yokosuka City Hospital, Kanagawa

われわれは腐蝕性食道炎に合併した食道癌症例を経験したので報告する。

症例は無下困難を主訴とする75藏の男性で，51年前自殺目的で硫酸を飲み，食道に広

汎なる派痕㹟窄を残す， 4 年前の上部消化管造影では狭窄がみられるのみであったが，

入院時は漏斗型の完全閉塞であり，生検にて扁平上皮癌と診断された。術前 ${ }^{60} \mathrm{Co} 3,000$ $\mathrm{rad}$ 照射し，胸部食道切除術を施行したが，術中所見は $\mathrm{N}_{0} \mathrm{Pl}_{0} \mathrm{M}_{0} \mathrm{H}_{0} \mathrm{~A}_{1}$ であった，組 織所見は粘膜下層より筋層にかけて広汎な線維化・炎症細胞浸潤があり，その中に中分 化型扁平上皮癌が散在していた，取扱い規約上 $\mathrm{mp}(+), \mathrm{a}_{0}, \mathrm{n}_{0}, \mathrm{ly}(+)$ であった。

腐蝕性食道炎より癌が発生する機序として，(1) 症痕癌説，(2) 刺激説，（3）栄養障 害説などがあげられる．本邦報告例ではいずれる刺激が重要なる発生原因と考えられる

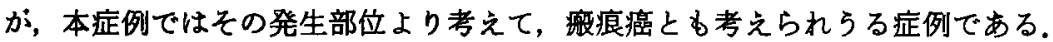

このように腐蝕性食道焱は種々の機序により食道癌の発生母地と考えられるので, 十 分なる follow up が必要であり，高度の狭窄例に対して積極的な食道切除が必要と考え られる.

柬引用語：腐触性食道炎, 食道癌, 瘵痕癌.

1)はじめに

食道癌の病因についていまだ定説がなく，多くの面 からその病因が追求されている，腐蝕性食道炎は食道 癌の発生母地と考えられているが，本邦ではその報告 例は稀であった，最近われわれは腐蝕性食道炎に合併 した食道癌症例を経験したので，本邦報告例の 4 例を 中心に文献的考察を加え報告する。

\section{2) 症 例}

症例：75歳，男性.

主訴：㬐下困難.
家族歴：特記することはない。

既往歴：昭和28年より精神分裂病のため精神病院に 入院加療中であった。

現病歴：51年前 (24歳時) 自殺の目的で硫酸を领み， 食道に広汎な激痕狭窄を残した。 その後数度のブジー による拻張療法を受け，常食摂取可能となっていた。 昭和53年 3 月の上部消化管造影（図 1) では下部食道 に狭窄があったが造影剤の通過は良好で，悪性所見は なく，胃の変形すなかった。昭和57年 7 月より睘下困 難が増強し，8月30日当科に入院した。 
入院時現症：身長 $151 \mathrm{~cm}$. 体重 $34 \mathrm{~kg}$ でるいそうを認 めるが，他には異常所見を認めなかった。

入院時検査成樍：表 1 の上5 亿呼吸機能検査で拘束 性障害を認めるが，他には異常なかった。

食道 X線所見：胸部中部食道に漏斗型の完全閉塞が みられた（图 2).
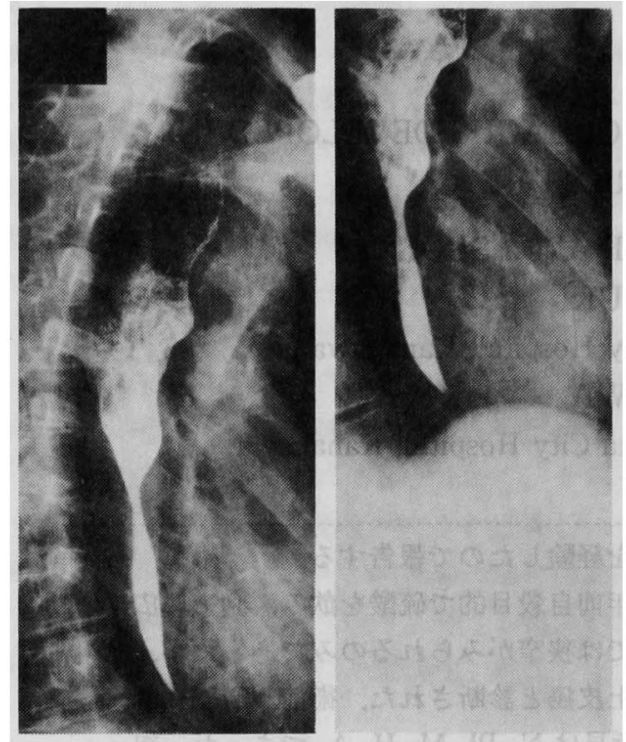

图 1 道造影(昭和53年 3 月)：胸部下部食道中心に 㹟窄がみられ，口側は軽度拡張している。

\section{表 1 入院時検查所見}

(1) 末梢血液

WBC 9400, RBC $543 \times 10^{4}$, Hb 16.6, Het 47 , Plt $28.0 \times 10^{4}$

（2）出血频固；w.n.1.

（3）尿一般；w.n.l.

（4）血液生化学

T.P 7.6, A/G 1.05, T.Bil 0.7, D-Bil 0.2, BUN

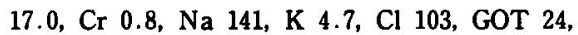
GPT 11, TTT 1.1, ZTT 24.2, ALP 3.6, LDH 361, ChE 0.58, AMY 80

(5) 血液ガス(R.A. Spont)

pH 7,425, $\mathrm{PaO}_{2}$ 98.9, $\mathrm{PaCO}_{2} 36.8, \mathrm{HCO}_{3}-23.8$, BE 0, $\mathrm{O}_{2}$-Sat 96.8

(6) 嗹㘼マーカー

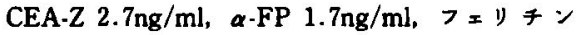
$470 \mathrm{ng} / \mathrm{ml}$

（7）呼吸機能

$\begin{array}{lllr}\text { VC } & 1.90 l & \text { \%VC } & 65.5 \% \\ \text { FEV }_{1.0} & 1.88 l & \text { \%FEV } & 100 \% \\ \text { MVV } & 28.3 l & \text { \%MVV } & 48.9 \%\end{array}$

食道内視篭所見：門歯列より $24 \mathrm{~cm}$ の部から粘莫は 灰白色を呈し，一部に結節がみられた。 $28 \mathrm{~cm}$ の部で全 周性に狭窄し，内視鏡の挿入は不可能であった。生検 で中分化型扁平上皮癌を認めた（図 3 ）.

治癔及ひ経過： ${ }^{60} \mathrm{Co} 3,000 \mathrm{rad}$ 術前照射の後，昭和 57年10月19日胸部食道切除術を施行した。手術所見は, $\mathrm{N}_{1}$ (一), $\mathrm{Pl}_{0}, \mathrm{M}_{0}, \mathrm{H}_{0}, \mathrm{~A}_{1}$, stage II であったが, 術心

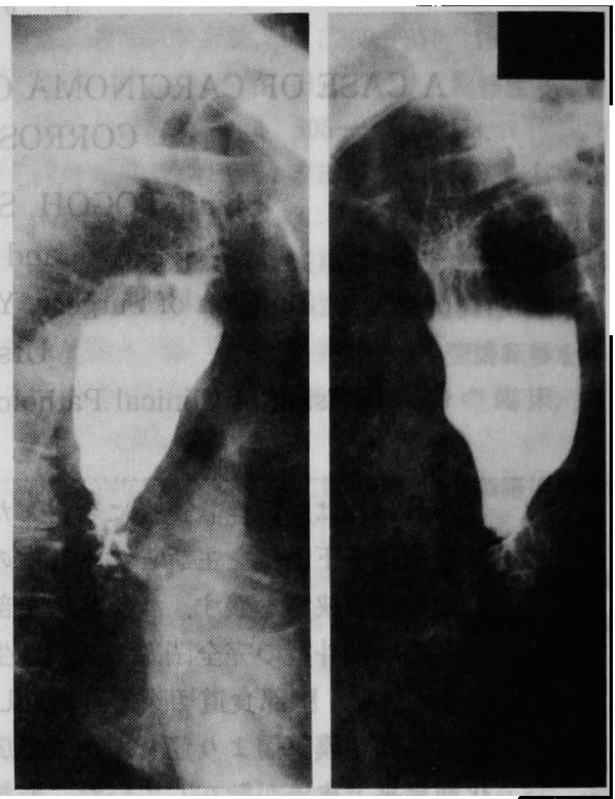

图 2 入院時串道造影(昭和57年 9 月)：胸部中部食道 に漏斗型の完全閉塞がみられる.

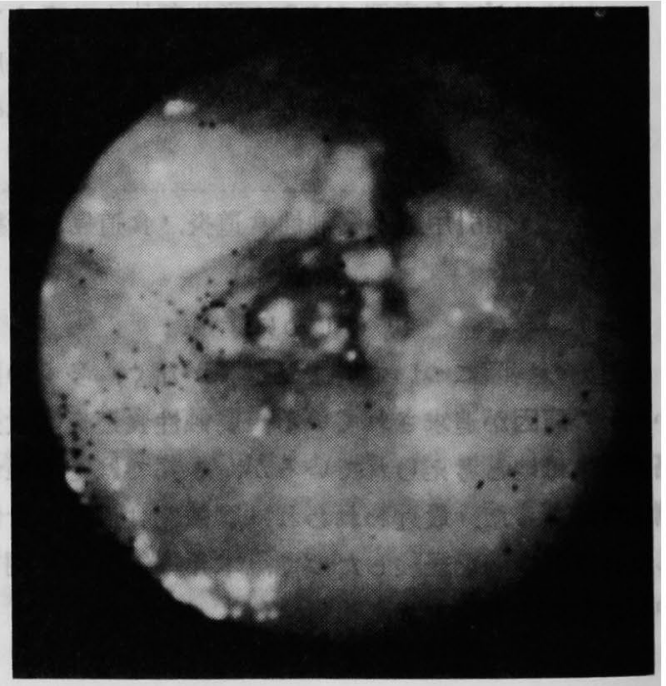

图 3 入院時食道内視金(昭和57年 9月):門歯より28 $\mathrm{cm}$ 部で全周性に狭窄像を量している. 


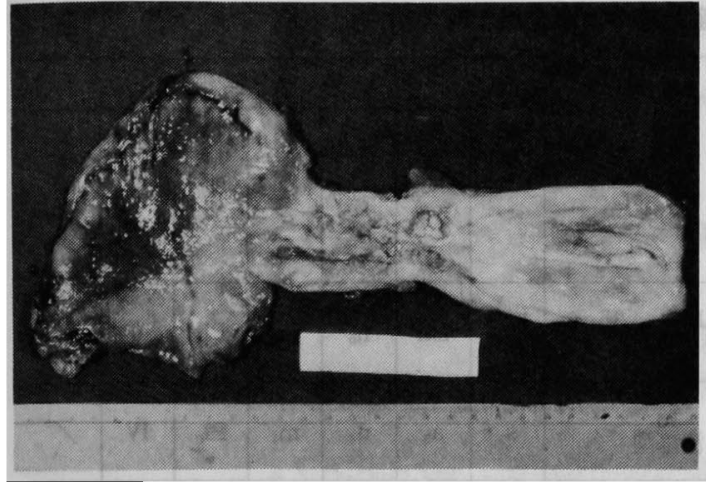

图4切除标本：Imより Eiにかけて食道左側壁を 中心に全国の4/5を占める浅い謴湯があり, 周辺に低

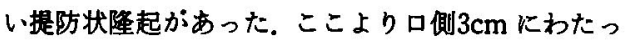
て粘膜は灰白色で肥厚していた。

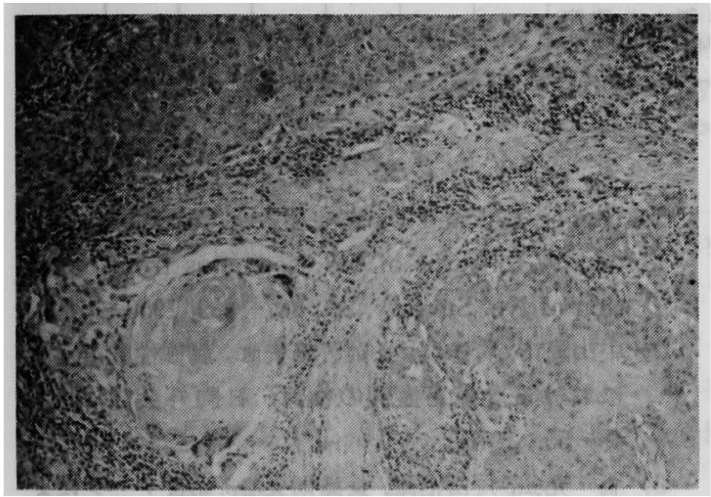

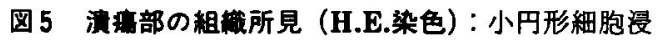
潤を伴う中分化型扁平上皮癌が存在し，一部瀤死部 分るみられる。

筋梗塞を併発し，同日死亡した。

切除栖本：Imより Ei にかけて食道左側壁を中心に 前後壁にわたり全周の4/5を占める大きさ $6 \times 2 \mathrm{~cm} の$ 浅い不整形の潰湯があり，その周囲に低い堤防状隆起 があった.ここから口側 $3 \mathrm{~cm}$ にわたって粘膜は灰白色 で便く肥厚していた（図4）.

倜学的所見：癌中心病巣は中分化型扁平上皮癌で あり，食道癌取扱い規約に従光ば $\mathrm{mp}(+), \mathrm{a}_{0}, \mathrm{n}_{0}, \mathrm{ly}$ (十), aw (一), ow (一) で, 照射効果は $\mathrm{Ef}_{1}$ であった (图 5 ).Azan-Malory 染色により切除口側端には広汎 な線永化がみられ，腐蝕性食道次と考えられた(图 6 )。

$$
\text { 3）考察 }
$$

属蝕性食道炎に合併した食道癌は, 1950年 Bigger \& Vinson が報告して以来外国では的100例を数えるが，

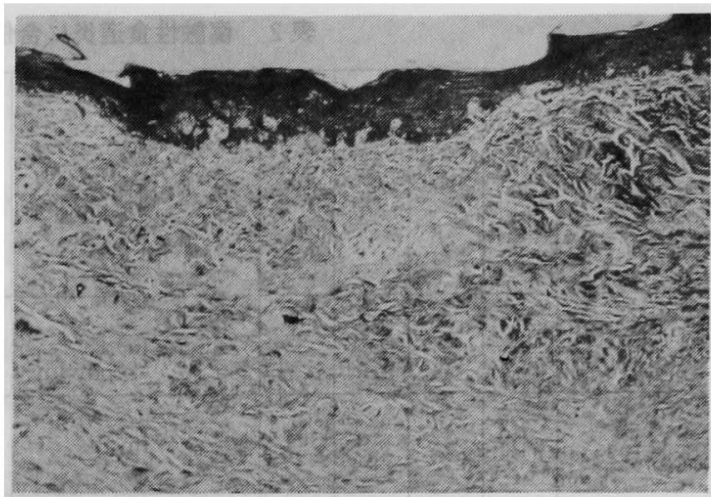

图 6 切除楼本口側の組織所見（Azan Malory 染 色）：㹟窄部に一致して粘膜下層より固有筋層に厇 汎なる線維化 (瘤痕) を認める。

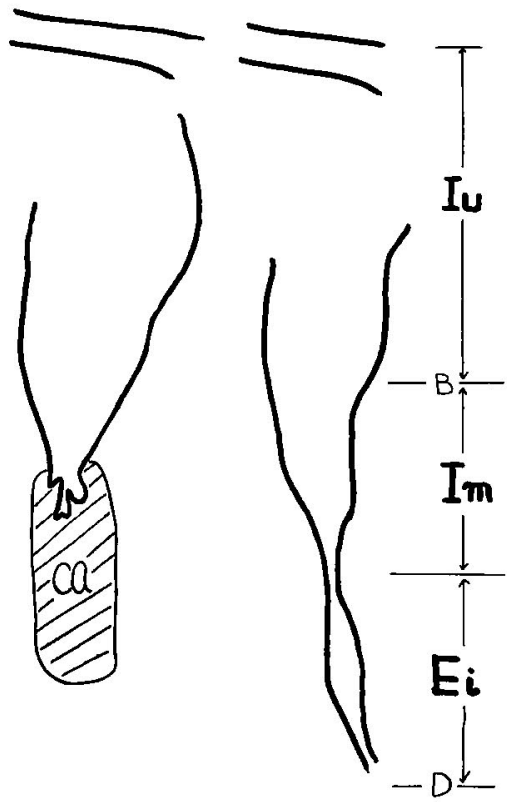

図 7 昭和53年と57年の食道造影の模式図

本邦では稀で, 昭和58年 5 月の第34回食道疾患研究会 で腐蝕性食道炎218例の検討が行なわれたが,このうち 12例の食道癌併発例が報告されたまた文献では 4 例 の報告を見るにすぎない(表 2)，通常の食道癌に比し 若年層に発生し，珄差がなく，癌発生までの期間は 16４2年（平均31年）といわれている，腐蝕性食道炎 に食道癌が続発する頻度は2.4〜5.2\%とされている が, 同年代の健康人に比し $22 \sim 1,000$ 倍も発生しやすい といわれている.

発生機序については，皮庙の熱傷郎痕により有栜細 


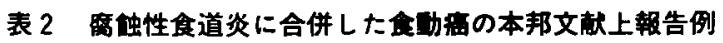

\begin{tabular}{|c|c|c|c|c|c|c|c|c|c|c|c|c|c|}
\hline \multirow[b]{2}{*}{$\begin{array}{l}\text { 辕 } \\
\text { 者 }\end{array}$} & \multirow[b]{2}{*}{$\begin{array}{l}\text { 発 } \\
\text { 犨 } \\
\text { 踰 }\end{array}$} & \multirow[b]{2}{*}{ 性 } & \multirow[b]{2}{*}{ 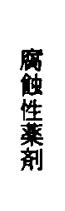 } & \multirow[b]{2}{*}{ 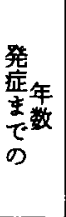 } & \multirow[b]{2}{*}{ 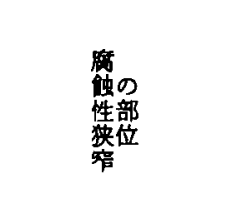 } & \multirow[b]{2}{*}{ 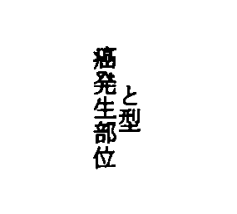 } & \multicolumn{7}{|c|}{ 病 } \\
\hline & & & & & & & 細 & $\begin{array}{l}\text { 粱 } \\
\text { 熱 }\end{array}$ & 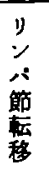 & 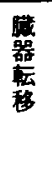 & 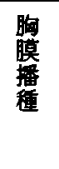 & $\begin{array}{l}\text { 準 } \\
\text { 度 }\end{array}$ & $\begin{array}{l}\text { 㢣 } \\
\text { 維 } \\
\text { 架 }\end{array}$ \\
\hline $\begin{array}{l}\text { 中 山2) } \\
(1976)\end{array}$ & 53 & ㅇ & 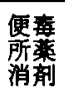 & 33 & $\begin{array}{l}\text { 門歯上り } \\
15 \mathrm{~cm}(\mathrm{Iu}) と \\
27 \mathrm{~cm}(\mathrm{Im})\end{array}$ & 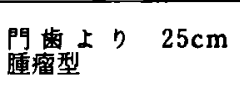 & $s_{q}$ & $\mathrm{sm}$ & $\mathrm{n}_{0}$ & $\mathrm{~m}_{0}$ & $\mathrm{PI}_{0}$ & 0 & $\mathrm{Ef}_{2}$ \\
\hline $\begin{array}{l}\text { 塎 J) } \\
(1979)\end{array}$ & 47 & 우 & $\begin{array}{l}\text { 苛” } \\
\text { 性多 }\end{array}$ & 24 & Im & 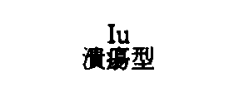 & $s_{q}$ & $a_{3}$ & $n_{4}$ & $\mathrm{~m}_{1}$ & $\mathrm{Pl}_{0}$ & IV & / \\
\hline $\begin{array}{l}\text { 福 田4) } \\
\text { (1980) }\end{array}$ & 47 & ㅇ & $\begin{array}{l}\text { 塩 } \\
\text { 酸 }\end{array}$ & 29 & $\begin{array}{l}\text { 門歯より } \\
23 \mathrm{~cm} \\
\text { (Iu) }\end{array}$ & 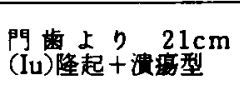 & $\mathrm{s}_{\mathrm{q}}$ & $\mathrm{sm}$ & $\mathrm{n}_{0}$ & $\mathrm{~m}_{0}$ & $\mathrm{Pl}_{0}$ & 0 & $E f_{1}$ \\
\hline 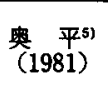 & 62 & $\hat{\delta}$ & $\begin{array}{l}\text { 苛y } \\
\text { 性如 }\end{array}$ & 30 & Ei & $10 \mathrm{~cm}$ 口側 & $s_{q}$ & $a_{3}$ & $\mathrm{n}_{0}$ & $\mathrm{~m}_{0}$ & $\mathrm{Pl}_{0}$ & IV & $E f_{z}$ \\
\hline 本 例 & 75 & $\hat{\delta}$ & 酼 & 51 & Im & 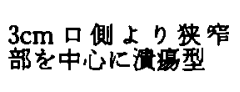 & $s_{q}$ & $\mathrm{mp}$ & $\mathrm{n}_{0}$ & $\mathrm{~m}_{0}$ & $\mathrm{Pl}_{\mathbf{0}}$ & I & $\mathrm{Ef}_{\mathrm{f}}$ \\
\hline
\end{tabular}

胞癌が発生するのと同様の機序による痗痕癌説, 腐蝕 により変形し可動性を失った状態の粘膜に長年にわた り機械的または化学的刺激が加わって癌が発生すると いう刺激説，長期に亘る释口栄養摄取障害に基つく栄 羕障害説がある，本邦報告例はいずれる狭窄より口側 に発生しており，これらでは刺激が重要な発生原因と 考えられる。本症例では狭窄の口側部にも癌は存在す るが，癌の中心は狭窄部内であり，洀痕癌とも考えら れる.

いずれにしても腐蝕性食道资は種々の機序により食 道癌の発生母地之考えられるので, 定期的な食道造 影・内視鏡による follow upが必要である。また狭窄 が高度であれば発癌の危険す考えて, 積極的な食道切 除が必要と考えられる。

$$
\text { 4) まとめ }
$$

75歳とい5高龄で癌発生まで51年とい5長期間を要 し，洀痕癌とも考えられる腐蝕性食道炎に合併した食 道癌症例を経験したので文献的考察を加充報告した。 また発癌前の腐蝕性食道炎による秋窄のX線撮影の記 録が残っておりこの点でも貴重な症例と考えられた。

稿を終えるにあたり御校閲を睗った横浜市立大学医学部 第 2 外科学教室土屋周二教授に深謝致します。

な㧍本文の要旨は第709回外科集談会にて発表した。

\section{文献}

1) Bigger, I.A. and Vinson, P.P.: Carcinoma secondary to burns of the esophagus from ingestion of lye. Surgery, 28: 887-889, 1950.

2) 中山隆市, 青木明人, 岡芹繁夫他: 腐蝕性食道狭窄 に招ける食道癌症例の検討, 日胸外会誌, 24： 48一55, 1976.

3）塙 充弘, 戸田治雄, 長島則夫他：苛性ソーダによ る腐蝕性食道損㥂後24年を経過して発症した食道 癌の 1 剖検例, 内科, $44: 490-494 ， 1979$.

4）福田敬宏, 田島昭三, 松本满臣他：屚触性食道㹧窄 に併発した食道癌の 1 例, 日気食会啹，31： 219-222, 1980.

5）奥平恭之, 上尾裕昭, 池田正亡他：腐蝕性食道狭窄 に続発した食道癌の 1 治験例，外科診療，23： $228-230,1981$.

6) Bigelow, N.H.: Carcinoma of the esophagus developing at the site of lye stricture. Cancer, 6 : 1159-1164, 1953.

7) Kiviranta, U.K.: Corrosion carcinoma of the esophagus. Acta Otolaryng, 42 : 89-95, 1952.

8) Joske, R.A. and Benedict, E.B.: The role of benign esophageal obstruction in the development of the esophagus. Gastroenterology, 36: 749-755, 1959. 